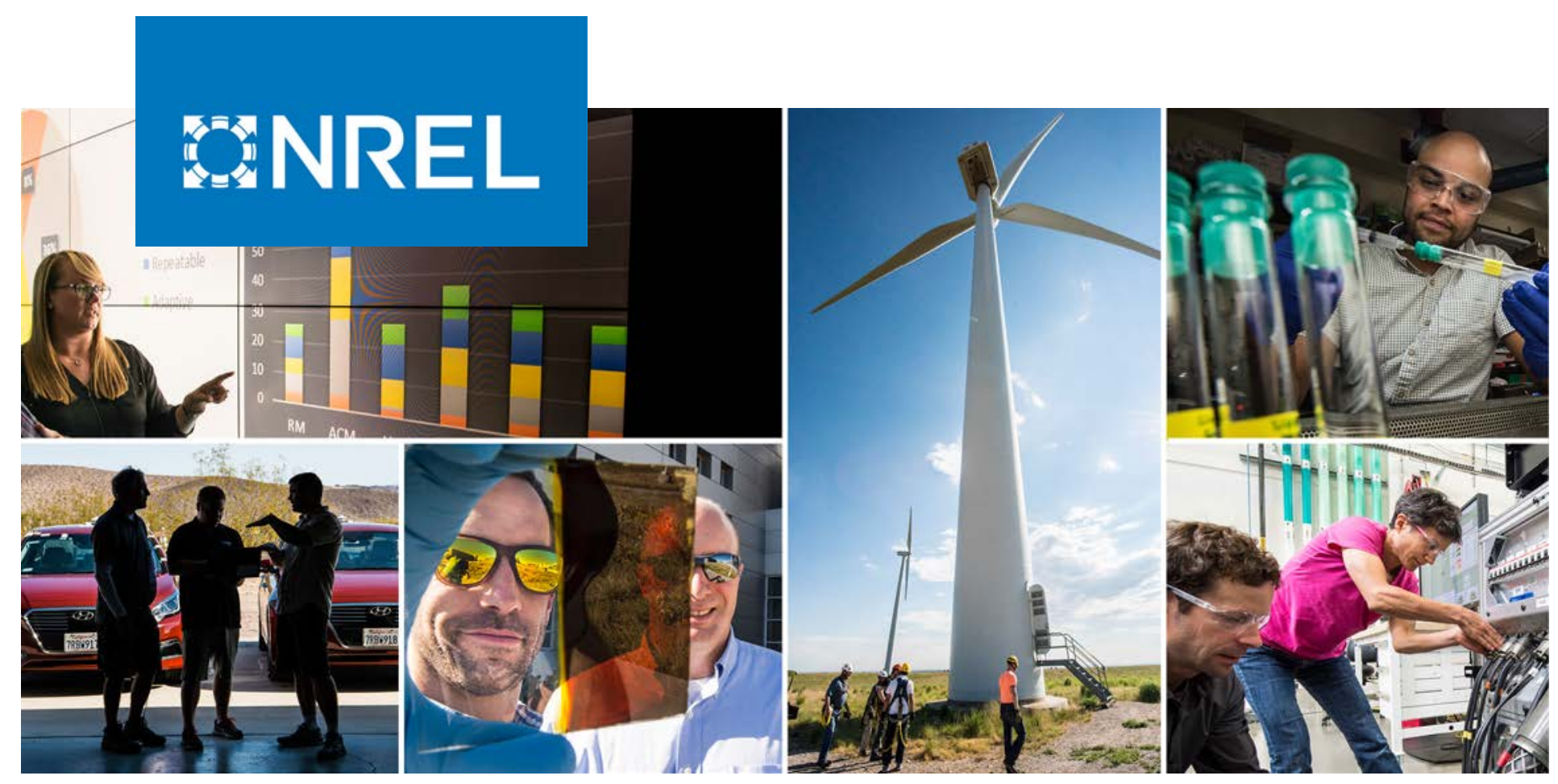

\title{
Recent HVPE Grown Solar Cells at NREL
}

\section{Preprint}

John Simon, Dennice M. Roberts, Jacob Boyer, Kevin L. Schulte, Anna Braun, Allison N. Perna, and Aaron J. Ptak National Renewable Energy Laboratory

Presented at the 48th IEEE Photovoltaic Specialists Conference (PVSC 48) June 20-25, 2021

NREL is a national laboratory of the U.S. Department of Energy Office of Energy Efficiency \& Renewable Energy

Operated by the Alliance for Sustainable Energy, LLC

This report is available at no cost from the National Renewable Energy Laboratory (NREL) at www.nrel.gov/publications.

\section{Conference Paper}

NREL/CP-5900-82237

February 2022 


\title{
GNREL
}

\section{Recent HVPE Grown Solar Cells at NREL}

\section{Preprint}

\author{
John Simon, Dennice M. Roberts, Jacob Boyer, Kevin L. \\ Schulte, Anna Braun, Allison N. Perna, and Aaron J. Ptak \\ National Renewable Energy Laboratory
}

\section{Suggested Citation}

Simon, John, Dennice M. Roberts, Jacob Boyer, Kevin L. Schulte, Anna Braun, Allison N. Perna, and Aaron J. Ptak. 2022. Recent HVPE Grown Solar Cells at NREL: Preprint. Golden, CO: National Renewable Energy Laboratory. NREL/CP-5900-82237

https://www.nrel.gov/docs/fy22osti/82237.pdf.

\begin{abstract}
(C) 2022 IEEE. Personal use of this material is permitted. Permission from IEEE must be obtained for all other uses, in any current or future media, including reprinting/republishing this material for advertising or promotional purposes, creating new collective works, for resale or redistribution to servers or lists, or reuse of any copyrighted component of this work in other works.
\end{abstract}

NREL is a national laboratory of the U.S. Department of Energy Office of Energy Efficiency \& Renewable Energy Operated by the Alliance for Sustainable Energy, LLC

This report is available at no cost from the National Renewable Energy Laboratory (NREL) at www.nrel.gov/publications.

Contract No. DE-AC36-08GO28308
Conference Paper

NREL/CP-5900-82237

February 2022

National Renewable Energy Laboratory 15013 Denver West Parkway Golden, CO 80401

303-275-3000 • www.nrel.gov 


\section{NOTICE}

This work was authored by the National Renewable Energy Laboratory, operated by Alliance for Sustainable Energy, LLC, for the U.S. Department of Energy (DOE) under Contract No. DE-AC36-08GO28308. The information, data, or work presented herein was partially funded by the Advanced Research Projects Agency - Energy (ARPAE), U.S. Department of Energy, award \#15/CJ000/07/05 and the DOE's Office of Energy Efficiency and Renewable Energy (EERE) under Solar Energy Technologies Office (SETO) Agreement Number 34358. The views expressed herein do not necessarily represent the views of the DOE or the U.S. Government. The U.S. Government retains and the publisher, by accepting the article for publication, acknowledges that the U.S. Government retains a nonexclusive, paid-up, irrevocable, worldwide license to publish or reproduce the published form of this work, or allow others to do so, for U.S. Government purposes.

This report is available at no cost from the National Renewable Energy Laboratory (NREL) at www.nrel.gov/publications.

U.S. Department of Energy (DOE) reports produced after 1991 and a growing number of pre-1991 documents are available free via www.OSTI.gov.

Cover Photos by Dennis Schroeder: (clockwise, left to right) NREL 51934, NREL 45897, NREL 42160, NREL 45891, NREL 48097, NREL 46526.

NREL prints on paper that contains recycled content. 


\title{
Recent HVPE grown solar cells at NREL
}

\author{
John Simon, Dennice M. Roberts, Jacob Boyer, Kevin L. Schulte, Anna Braun, Allison N. Perna, and Aaron \\ J. Ptak
}

National Renewable Energy Laboratory, Golden, CO, USA

\begin{abstract}
In this work we present solar cells grown via hydride vapor phase epitaxy (HVPE) in NREL's dynamic HVPE reactor. We show single junction GaAs and GaInP solar cells with efficiencies as high as $\mathbf{2 5 . 5 \%}$ and $\mathbf{1 5 . 2 \%}$ respectively, and dual junction solar cells with an efficiency of $24.9 \%$.
\end{abstract}

\section{Keywords-III-V solar cells, GaAs, GaInP, HVPE}

\section{INTRODUCTION}

III-V materials have achieved the highest solar cell efficiencies in both single and multi-junction configurations[1]. Their strong absorption coefficients permit the formation of thin structures that are flexible and light, but still optically thick, enabling improved energy harvesting. Despite all of their advantages, III-Vs are limited to highvalue applications such as space power primarily due to their high manufacturing costs [2]. Hydride vapor phase epitaxy (HVPE) has emerged as a potential lower cost alternative to current manufacturing processes of III-V solar cells [3, 4]. In this work, we highlight recent advances at NREL in the use of dynamic-HVPE (D-HVPE) to obtain high efficiency single and dual junction solar cells. D-HVPE uses multiple adjacent HVPE chambers to generate high quality interfaces needed for optoelectronic devices[5]. This has made it possible for us to demonstrate single junction $\mathrm{GaAs}[3]$ and GaInP[6] solar cells, tunnel junctions[7], and tandem devices[8]. We will show progress in improving the performance of these devices, enabling us to reach efficiencies $>25 \%$ for single-junction GaAs devices.
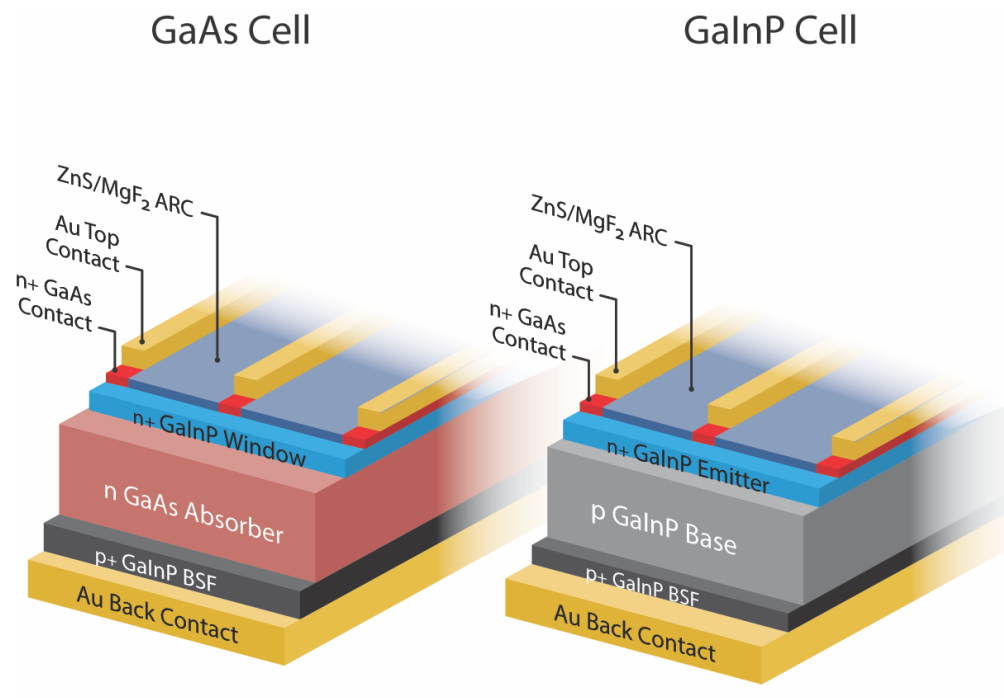

Fig 1. Structure of GaAs (left), GaInP (middle) and tandem (right) cells used in this work.

\section{EXPERIMENTAL METHODS}

Solar cells were grown in our dual growth chamber D$\mathrm{HVPE}$ reactor[5] using pure $\mathrm{Ga}$ and $\mathrm{In}$ metal, $\mathrm{HCl}, \mathrm{AsH}_{3}$, and $\mathrm{PH}_{3}$, with a $\mathrm{H}_{2}$ carrier gas. Dilute $\mathrm{H}_{2} \mathrm{Se}$ was the n-type dopant, while diethylzinc was the p-type dopant. Heterointerfaces were formed by rapid mechanical transfer of the substrate between the two growth chambers, with each chamber stabilized at a new growth condition (either a change in material, doping, or both). Substrates were (100) n+ GaAs doped with $\mathrm{Si}$ and offcut $6^{\circ}$ towards the (111)A plane. The growth rates of the thick $\mathrm{Ga} 0.5 \mathrm{In}_{0.5} \mathrm{P}$ and $\mathrm{GaAs}$ absorber layers were 0.9 and $1.0 \mu \mathrm{m} / \mathrm{min}$, respectively. The structures, shown in Fig. 1, were grown in an inverted fashion and processed using the method detailed in ref. [9]. Ni/Au front contact grids and $\mathrm{Au}$ metal were used for the front and back contacts respectively. External quantum efficiency (EQE) was measured on a custom instrument using LED illumination (470 and $850 \mathrm{~nm}$ ) to limit each individual subcell in the tandem devices, allowing measurement of individual subcell EQE. The spectral reflectance was measured and used to calculate the internal quantum efficiency (IQE) of each cell. The solar cell one-sun AM1.5G current density-voltage $(J-V)$ curves were measured under a calibrated spectrum using separate reference cells for each cell. All simulator measurements were certified by the PV performance characterization team at NREL.

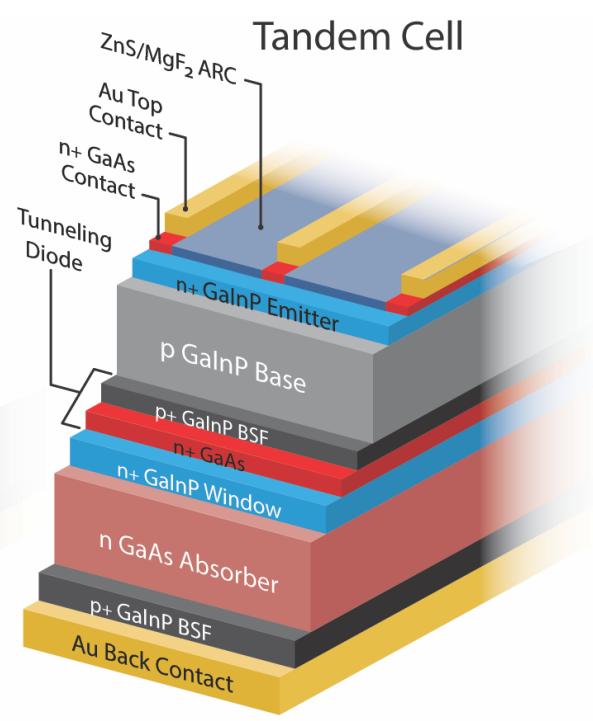




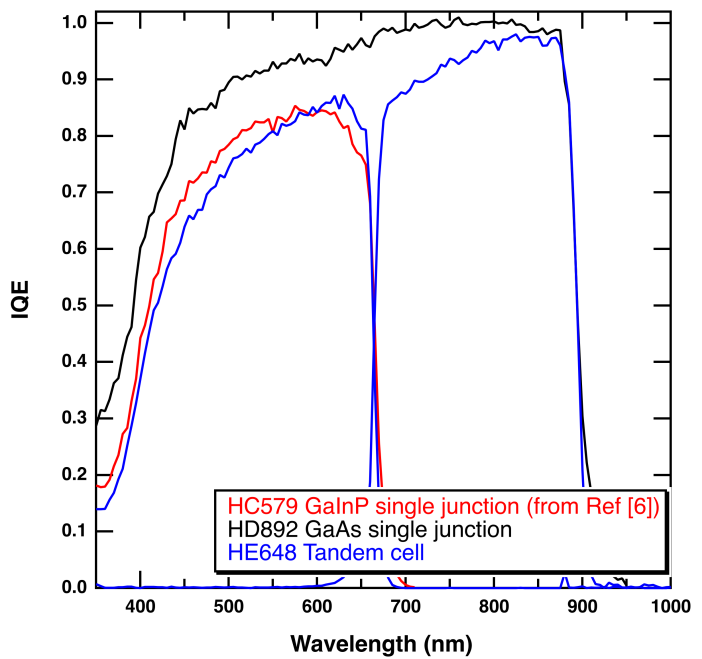

Fig 2. IQE of GaInP (red), GaAs (black), and a GaInP/GaAs tandem cell (blue) grown by D-HVPE.

\section{RESULTS}

Fig. 2 shows the IQE of each type of cell. The near unity IQE of the single junction GaAs cell near the bandedge showcases the high collection efficiency of the D-HVPE devices. Both the GaInP cell and the tandem device collection is limited by the unpassivated GaInP emitter (see Fig. 1).

Table I shows a summary of the certified solar cell measurements. The highest GaAs and GaInP single junction cell efficiencies achieved are $25.5 \%$ and $15.2 \%[6]$, respectively. Fig. 3 shows the certified $J-V$ characteristics. The dual junction tandem devices, limited by the top cell current[10], achieved an efficiency as high as $24.9 \%$.

TABLE I. CERTIFIED ONE-SUN SOlAR CELl DATA

\begin{tabular}{|c|c|c|c|c|c|}
\hline Cell & Type & $\begin{array}{c}\text { Voc } \\
(\boldsymbol{V})\end{array}$ & $\begin{array}{c}\boldsymbol{J}_{\boldsymbol{S C}} \\
\left(\boldsymbol{m} \boldsymbol{A} / \boldsymbol{c m}^{2}\right)\end{array}$ & $\begin{array}{c}\boldsymbol{F F} \\
(\%)\end{array}$ & $\begin{array}{c}\boldsymbol{\eta} \\
(\%)\end{array}$ \\
\hline HD892 & GaAs & 1.08 & 27.8 & 85.1 & 25.5 \\
\hline HC579 & GaInP & 1.35 & 13.0 & 86.7 & 15.2 \\
\hline
\end{tabular}

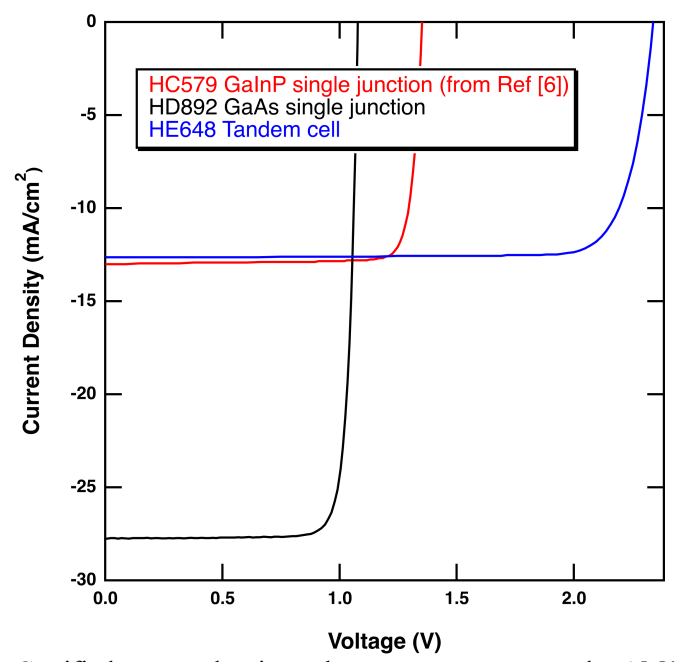

Fig 3. Certified current density-voltage measurements under AM1.5G conditions for $\mathrm{GaInP}$ (red), GaAs (black), and a $\mathrm{GaInP} / \mathrm{GaAs}$ tandem cell (blue) grown by D-HVPE.

\begin{tabular}{|c|c|c|c|c|c|}
\hline Cell & Type & $\begin{array}{c}\text { Voc } \\
(\boldsymbol{V})\end{array}$ & $\begin{array}{c}\boldsymbol{J}_{\boldsymbol{S C}} \\
\left(\boldsymbol{m} \boldsymbol{A} / \boldsymbol{c m}^{2}\right)\end{array}$ & $\begin{array}{c}\boldsymbol{F F} \\
(\boldsymbol{\%})\end{array}$ & $\begin{array}{c}\boldsymbol{\eta} \\
(\%)\end{array}$ \\
\hline HE648 & Tandem & 2.34 & 12.6 & 84.3 & 24.9 \\
\hline
\end{tabular}

\section{CONCLUSION}

We produced high efficiency solar cells via D-HVPE. We obtained certified efficiencies as high as $15.2 \%$ and $25.5 \%$ for single junction GaInP and GaAs solar cells, respectively. Dual junction $\mathrm{GaInP} / \mathrm{GaAs}$ solar cells show efficiencies as high as $24.9 \%$ despite the lack of front-surface passivation. In the future, we will use higher bandgap materials[11, 12] to improve the top GaInP solar cell passivation to enhance the efficiency of both the single junction top cell and tandem devices.

\section{ACKNOWLEDGMENT}

The authors would like to acknowledge David Guiling for materials growth and Evan Wong for cell processing. This work was authored by Alliance for Sustainable Energy, LLC, the manager and operator of the National Renewable Energy Laboratory for the U.S. Department of Energy (DOE) under Contract No. DE-AC36-08GO28308. The information, data, or work presented herein was partially funded by the Advanced Research Projects Agency - Energy (ARPA-E), U.S. Department of Energy, award \#15/CJ000/07/05 and the DOE's Office of Energy Efficiency and Renewable Energy (EERE) under Solar Energy Technologies Office (SETO) Agreement Number 34358. The views expressed in the article do not necessarily represent the views of the DOE or the U.S. Government. The U.S. Government retains and the publisher, by accepting the article for publication, acknowledges that the U.S. Government retains a nonexclusive, paid-up, irrevocable, worldwide license to publish or reproduce the published form of this work, or allow others to do so, for U.S. Government purposes.

\section{REFERENCES}

[1] M. Green, E. Dunlop, J. Hohl-Ebinger, M. Yoshita, N. Kopidakis, and X. Hao, "Solar cell efficiency tables (version 57)," Progress in Photovoltaics: Research and Applications, vol. 29, no. 1, pp. 3-15, 2021, doi: https://doi.org/10.1002/pip.3371.

[2] K. A. Horowitz, M. Woodhouse, H. Lee, and G. P. Smestad, "A bottom-up cost analysis of a high concentration PV module," in AIP Conference Proceedings, 2015, vol. 1679, no. 1: AIP Publishing, p. 100001.

[3] J. Simon, K. L. Schulte, K. A. W. Horowitz, T. Remo, D. L. Young, and A. J. Ptak, "III-V-Based Optoelectronics with Low-Cost Dynamic Hydride Vapor Phase Epitaxy," Crystals, vol. 9, no. 1, p. 3, 2018. [Online]. Available: http://www.mdpi.com/2073-4352/9/1/3.

[4] K. A. W. Horowitz, T. Remo, B. Smith, and A. Ptak, "A TechnoEconomic Analysis and Cost Reduction Roadmap for III-V Solar Cells," 2018. [Online]. Available: https://www.nrel.gov/docs/fy19osti/72103.pdf

[5] D. L. Young, A. J. Ptak, T. F. Kuech, K. Schulte, and J. D. Simon, "High throughput semiconductor deposition system," Patent 9,824,890; Other: 14/801,551 United States Other: 14/801,551 NREL English, 2017. [Online]. Available:

http://www.osti.gov/scitech/servlets/purl/1409831

[6] K. L. Schulte, J. Simon, M. R. Young, and A. J. Ptak, "Improvement of Short-Circuit Current Density in GaInP Solar Cells Grown by Dynamic Hydride Vapor Phase Epitaxy," IEEE Journal of Photovoltaics, vol. 8, no. 6, pp. 1616-1620, 2018, doi: 10.1109/JPHOTOV.2018.2870938. 
[7] A. J. Ptak, J. Simon, K. L. Schulte, and N. Jain, "Tunnel Junction Development Using Hydride Vapor Phase Epitaxy," IEEE Journal of Photovoltaics, vol. 8, no. 1, pp. 322-326, 2018, doi:

10.1109/JPHOTOV.2017.2756566.

[8] K. L. Schulte, J. Simon, and A. Ptak, "Multijunction GaInP/GaAs Solar Cells Grown by Hydride Vapor Phase Epitaxy," Progress in Photovoltaics: Research and Applications, vol. 26, no. 11, pp. 887893, 2018, doi: 10.1002/pip.3027.

[9] A. Duda, J. S. Ward, and M. Young, "Inverted Metamorphic Multijunction (IMM) Cell Processing Instructions," National Renewable Energy Laboratory, 2012. [Online]. Available: http://www.nrel.gov/docs/fy120sti/54049.pdf
[10] K. L. Schulte, J. Simon, and A. J. Ptak, "Multijunction $\mathrm{Ga} 0.5 \mathrm{In} 0.5 \mathrm{P} / \mathrm{GaAs}$ solar cells grown by dynamic hydride vapor phase epitaxy," Progress in Photovoltaics: Research and Applications, vol. 26, no. 11, pp. 887-893, 2018, doi: https://doi.org/10.1002/pip.3027.

[11] K. L. Schulte et al., "Growth of AlGaAs, AlInP, and AlGaInP by Hydride Vapor Phase Epitaxy," ACS Applied Energy Materials, vol. 2, no. 12, pp. 8405-8410, 2019/12/23 2019, doi: 10.1021/acsaem.9b02080.

[12] Y. Shoji, R. Oshima, K. Makita, A. Ubukata, and T. Sugaya, "Epitaxial Lift-Off of Single-Junction GaAs Solar Cells Grown Via Hydride Vapor Phase Epitaxy," IEEE Journal of Photovoltaics, vol. 11, no. 1, pp. 93-98, 2021, doi: 10.1109/JPHOTOV.2020.3033420. 